\title{
BUILDING INFORMATION MODELING BIM - LEVEL OF DIGITAL CONSTRUCTION
}

\begin{abstract}
A. GLEMA ${ }^{1}$
Abstract

In the paper the topic of Building Information Technology BIM is investigated. It is new in Polish circumstances technology for construction and for building product industry, which contribute to change and develop level of industrialization. Especially challenge raising from the information and introducing IT technology into daily practice is considered to provide changes in construction branch of economy. In Poland there is the hot need of start to introduce BIM as the common technology for owners of assets, facility management, construction entities, design offices, administration officers and many other players relative to construction data and processes. BIM technology introduction, basing on foreign case studies, results in cost savings, control and time reduction of investment processes and some more advantages. The perspective of digital buildings, digital infrastructure, digital roads, digital railways and digital cities is outlined at the perspective of technology challenge, but simply transfiguration of many fields of personal everyday life, where digitalization is already present and with the question when it will be common in professional activity, particularly in civil engineering.
\end{abstract}

Keywords: construction engineering, information technology, CAD, BIM, digital economy, digital construction

\section{INTRODUCTION}

It is easy to see the technology changes, looking at different fields, starting from the conservative one as music, through tourism, photography or publishing, up to finances. One can recognize and understand how big possibilities raises from new information technologies, how the main branches

\footnotetext{
1 DSc., PhD., Eng., prof. PUT, Poznan University of Technology, Faculty of Civil and Environmental Engineering, Institute of Structural Engineering, ul. Piotrowo 5, 60-965 Poznan, Poland, e-mail: adam.glema@put.poznan.pl
} 
of industry undergo intensive modifications. Above mentioned and many others fields have been transformed due to progress in digital technology in the last two decades.

Up to now the construction industry and also building products areas are resistant to achievements that have been proceeded in other branches of industry. If the digital technology is present it is just side effect, not the core transformation.

However, such the combined components as BIM - building information modeling [1], global standards of data processing [2], 3D printing, as well as all findings to produce, install and assemble part of construction investment out of construction field affect construction industry. Traditional inertia is huge, but stress of side activity is strong. The important influence is also the way that generations coming into professional activity used apply IT technology in everyday life.

All new skills, adaptability of new technology will have crucial importance to provide improvement of industrialization, to constitute a necessary condition for survival, to extend management, that is based on knowledge and information. The knowledge-information base combined with the skillful delivery of services will be the key to future competitive advantage. There is an announcement to every construction organization and construction professionals: take care, adapt, do not miss, the digital construction is coming.

Statistics about simple digital elements in our world, our continents, our countries is astonishing. Statistical data of year 2014 and year 2015 for Poland have displayed the significant change.

For almost 39 million of citizens in Poland, number of active internet users is almost 26 million. 14 million, more then half of them, belong to snappy members of social media. Number of mobile devices, like notebooks, tablets and smartphones, is growing, number of mobile connections, number of mobile internet users, number of mobile social media members are displayed in Fig. 1. Poland now takes fifth place in European statistical ranking. It is basic obligatory requirement for the possibility of communication in more than half of Polish population, and not only young. But recognizing communication as the one of the primary property of information and informatics technology statistics show also huge digital potential. Looking at the other part of Fig. 1. Let's take the observation what is the speed of changes and application of information technology and how the extension of amount of information has become the practical evidence of single, average citizen. How you can imagine to use telegram. Message, what in those circumstances is the same as information, is no more recognized with piece of paper, as it is presented in Fig. 1. It is like the ancient history to thing that sending message SMS (short message service) is something similar to telegram and using paper. It is not only case of using paper, but engagement of post service, transportation, postman to deliver. It is not only the resources. There are two main factors : 
cost and time of process. How much money and how much time it is, if one compare ? There are exactly the same factors: cost and time, that are now discussed, when the implementation of building information modeling BIM is considered. The example and the figure display also other important and formal doubts around BIM. There are requirements, that paper form of information delivery is obligatory in many industry branches and in investment cases. Mentioned doubts around the BIM implementation also put the simple question if it is possible to use digital documentation, especially at construction field? Is the building field the place for mobile devices? But it is also easy to present threads of using new digital technology without obtaining benefits: using tablet as the only another

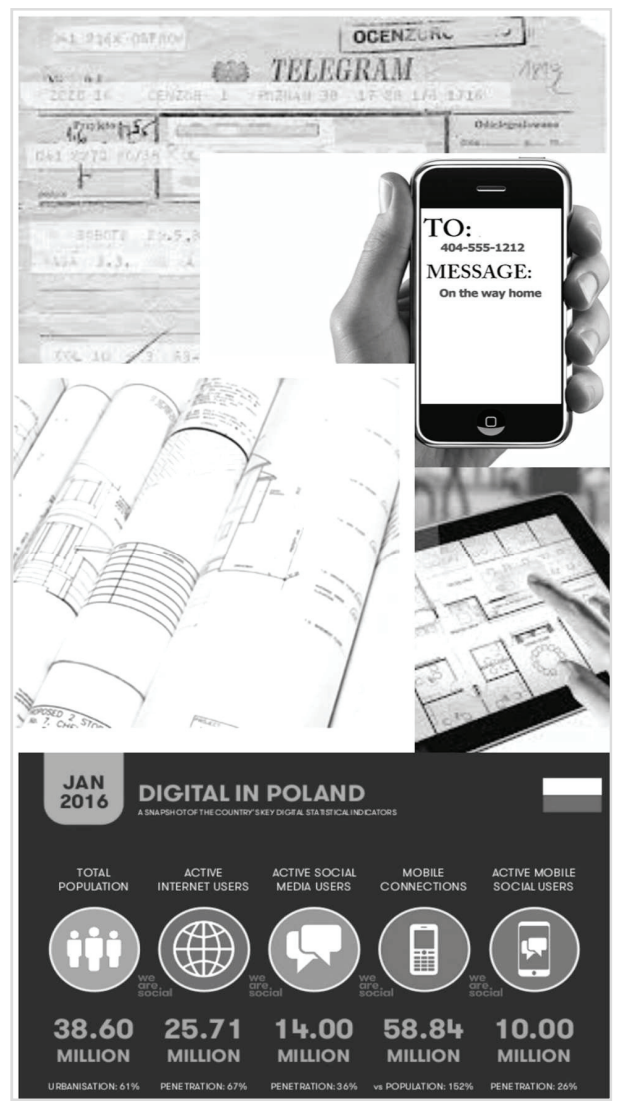

form of paper to look at construction documentation without digital profit.

Fig. 1. Information and its digital transformation in last years: an example of telegram and SMS, constructional documentation, statistics of digital activity in Poland in 2015. 


\section{BUILDING INFORMATION MODELING - BIM}

Many rather disparate definitions are available to describe what BIM means. Varying understandings of a single concept within a single field has already led to much unnecessary confusion and cross purposes. It is not good enough to say it means different things to different players (depending on discipline and background). However there is no single definition. One of the propositions defined in thesis [3] on implementation of BIM in Sweden gives:

Building Information Modeling is a process of representation, which creates and maintains multidimensional, data-rich views throughout a project lifecycle to support communication (sharing data); collaboration (acting on shared data); simulation (using data for prediction); and optimization (using feedback to improve design, documentation and delivery).

For more then ten year after starting the work on description of building information technology at the very end of 2012 year the three complementary definitions were published in the report of BuildingSmart International organization [4], using $\mathrm{M}$ as model, modeling or management:

\subsection{BUILDING INFORMATION MODEL}

is the DIGITAL REPRESENTATION of physical and functional characteristics of a facility. As such it serves as a shared knowledge resource for information about a facility, forming a reliable basis for decisions during its life-cycle from inception onwards.

\subsection{BUILDING INFORMATION MODELING}

is a BUSINESS PROCESS for generating and leveraging building data to design, construct and operate the building during its lifecycle. BIM allows all stakeholders to have access to the same information at the same time through interoperability between technology platforms.

\subsection{BUILDING INFORMATION MANAGEMENT}

is the ORGANIZATION\&CONTROL of the business process by utilizing the information in the digital prototype to effect the sharing of information over the entire lifecycle of an asset. The benefits include centralized and visual communication, early exploration of options, sustainability, efficient design, integration of disciplines, site control, as built documentation, etc. effectively developing an asset lifecycle process and model from conception to final retirement. 
BIM is based on fundamentals, which are 3D geometrical model of a building or infrastructure object, next data, next once more data, and once more data represented by processes. 3D geometry of a building or infrastructure object is data, as well. BIM data are formulated in international standard IFC Industry Foundation Classes (Fig. 2) [2, 5].

BIM technology is already in practice in United States, Scandinavia Region and United Kingdom. In last 2011-2016 years the most intensive program in popularization and obligation of BIM was applied in UK with the activity of HM Government and its dedicated agencies. A new project is announced by HM Government for next years, putting the Digital Build Britain [6] in the center.

The fundamental step for implementation of BIM technology has been performed in Poland in the middle of 2016 year [7, 8]. New Procurement Law for Poland [9] was enacted at the end of June 2016. Resolution after parliament and senate voting was published in the middle, and has come into force at the end of July 2016. According to regulations of Directive of the European Parliament and of the Council [10], that is referenced in Procurement Law in Poland, the article on building information modeling is strictly taken in the English version from Directive. It states that building information modeling may be required. Now after the middle of July 2016 we can state that in Poland we have the law record that makes possible to require by investor for any partner of conception, design, construction, operation etc. processes to use BIM technology in public investment. It is worth to add that in new version of Law of Public Procurement the ,life-cycle of building or infrastructure" is underlined as the important perspective to analyze the investment and management of real estate facilities and to have it in front of any economical, technical, social and environmental decision for construction industry. Now the investment and its cost are not in frames of design and general construction phase only, but are detailed according to needs of owner or facility management with range of whole time period of construction, especially the operation over several decades with such the scale of cost effectiveness observation and analysis.

Building Information Modeling (BIM) is already changing the UK construction industry - a vitally important sector that employs more than three million people and in 2010 delivered £107billion to the UK economy. Over the next decade this technology will combine with the internet of things (providing sensors and other information), advanced data analytics and the digital economy to enable us to plan new infrastructure more effectively, build it at lower cost and operate and maintain it more efficiently. 


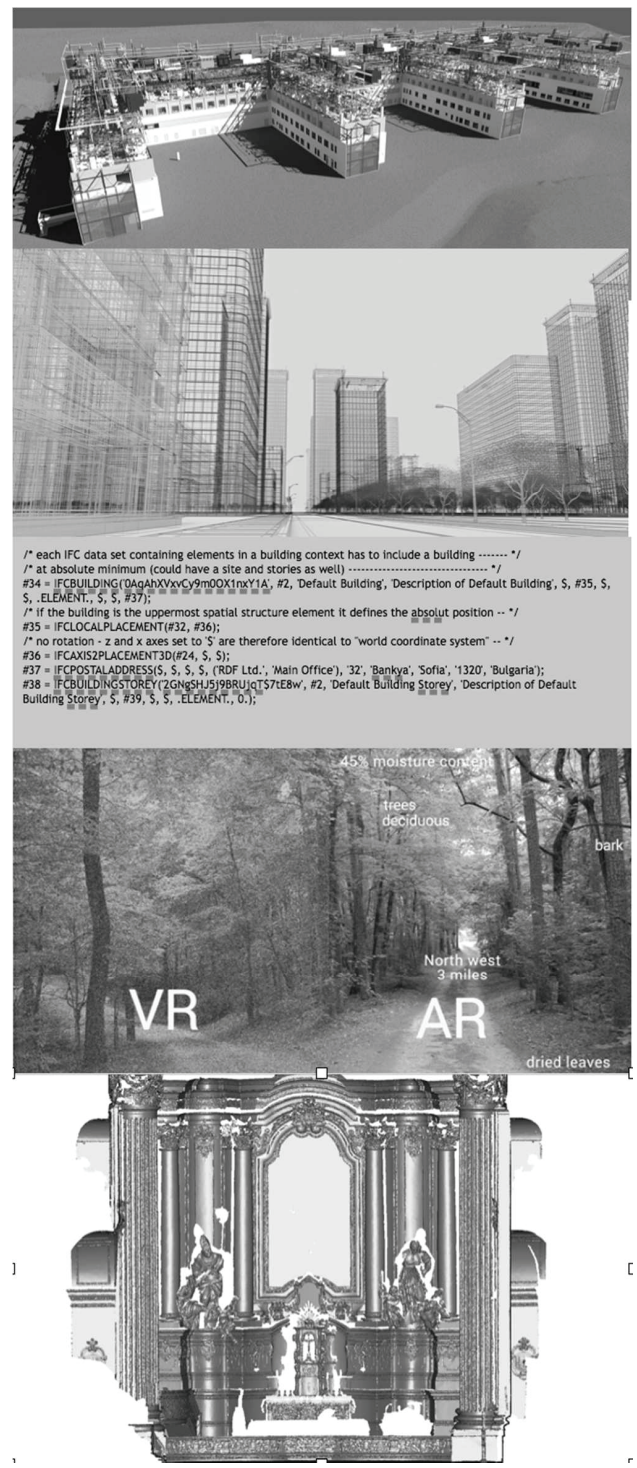

Fig. 2. Components of digital construction: example of BIM model of hospital consisted of architecture, construction and MEP modeling; digitalization for the street; example of IFC file -standard of building data import and export; wood as background of application of virtual reality and augmented reality; example of laser scanning of part of altar in Poznan Fara Church. 
One of case studies of implementation of BIM is Crossrail project for new transportation solution for London (Fig. 3). Above all, it will enable citizens to make better use of the infrastructure we already have. This is Digital Built Britain [6].

\section{REALITY AND DIGITAL WORLD}

Virtual Reality VR and Augmented Reality AV are two digital technologies that are bonded with reality. Both are links that are connected to totally different attachments (Fig. 2).

Virtual Reality implements the digital technology in order to percept the digital world as real. Augmented Reality employs digital technology in order to percept real world in digital form. Both technologies need more and more computer power. Soon both technologies will compete for our attention in everyday life and work in the construction and real estate.

Does the technology can serve for historical monuments, works of cultural heritage ?

Augmented Virtual Reality AVR is superposition of above technologies, VR + AR, AVR makes possible to percept digital world not only audio-visually, but supposed by digital data. The work on data that are displayed goes in the same time during observation of space visualization in digital form. This synchronization of visual form of digital world with data appended in various form of information is about this extension. Sometimes visual part of information perception is better to limit for data receiving in a better, not interfered way. The right composition of digital environment and adjusting of digital visualization is important to not make reception worse. Sometimes visual part of information receiving is better to restrict in order of get overall result communicative. The proper composition of digital range, adjusting of digital scene and data expanding perception of digital world, differentiation to current need are very important to obtain the aim of common application of digital construction technology by implementation to level of initial conception of investment, multidisciplinary designing, construction of building or infrastructure object and operation with facility management. In civil engineering a building, a road, a bridge for other object is a product with the very low chance to be repeated. Investment for such the object, from the point of view of serial production, when every building or infrastructure object is different and individual should go a bit different way. A method adjusted to the specific resolution should be taken. 


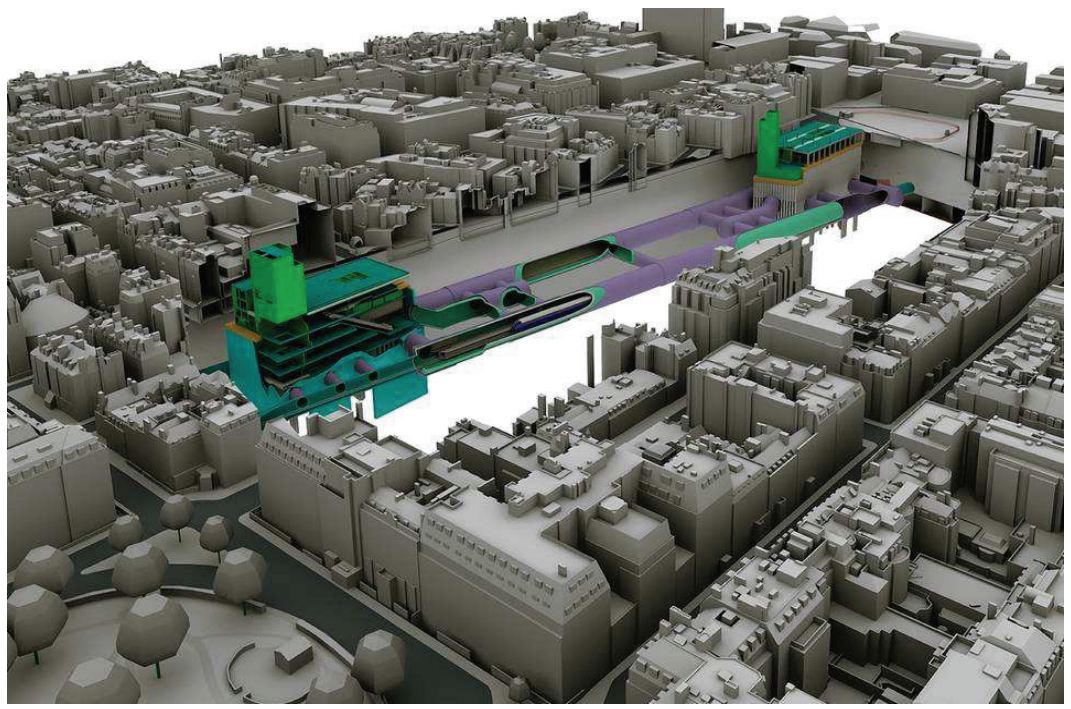

Fig. 3. Example of digital construction for infrastructure - CROSSRAIL project - metro station in London.

There is additional element of digital world and the milestone of information technology with the name of cloud computing, that has great potential for BIM development. Networks, servers, storage, applications and services are configurable resources with convenient, on-demand network access. The BIM technology consumer is able to use hardware, run software, access applications from various devices, storage building information model. Cloud computing in private, community, public or hybrid version fits different BIM needs and enhances modelers collaboration, designs checking, team working, construction documents on site excessing, project executing as well.

Building Information Modeling and Digital Construction make enable to construct the object of investment twice. First the BIM model is created and armed with rich characteristic of completion processes. This is the level of virtual construction. After employing wide set of software tools to control clushes, to control scheduling, to control organization of work in the field, etc. and after gaining hard piece of experience in substantial project multidisciplinary team with the investor as a head of the group can conclude that the first, virtual construction is executed. In digital world, many aspects of construction are updated using virtual reality tools at the design level from the engineering point of view. Design interoperates for some most part of construction phase. But what is here evident this digital construction with digital reality opens new opportunities for owner, investor, user of the building or infrastructure object to be familiar with the object, to meet its functionality and to recognize how the operation of the facility will look like, what will be the operational costs and 
general exploitation of object that is still only virtual. Civil engineering is a branch of industry there modification of the real state is often met in practice, is hard task, is expensive and usually results in irreversible effects. More and more mobile tools, starting from the very simple and inexpensive card board boxes, next more advance solutions like google glass or oculus rift and hololens support nowadays reception of virtual object. The separate story is about very advanced virtual technology solutions with virtual wall or virtual cave. One more thing that is worth to mention is the BIM room as the dedicated chamber in design office, but on building filed as well, where digital technology supports process of investments. After first virtual construction, the next, second real one is initiated. The real construction follows the first non-real construction. The second is more effective, the volume and cost of construction materials is lower, the coordination of processes is better, the quality of product is higher, the accuracy of elements is better, so the total investment presents lower risk and higher rate of interest. But the role of building information modeling and virtual reality continues over the moment of construction completion. BIM model, data, databases, are now in hands of professionals of real estate to serve during much longer, far away more economically important level of facility management. CAD does aid the design processes. BIM and Digital Construction is the information technology supporting all levels of construction and building products industry development.

\section{FINAL REMARKS}

Digital technologies for construction industry, as building information modeling BIM go far beyond the already popular computer aided design CAD. Numerical computations and even simulation of physical processes, and support of preparation and utilization of electronic building documentation are only parts that one can expect within digital construction.

Construction challenges for next ten years 2016-2025 are the following:

- more prefabrication,

- quality and dimensional accuracy,

- less waste and lean management,

- software is everywhere,

- internet of things and data,

- measuring and monitoring,

- big data, big models, big databases. 
Technique and technology are ready to explore the digital world. Digital scene and various technics of vision perception is significant part of digital world, digital construction, but prevailing part of digital area are data and their digital transformation with the bring into play the information technologies.

The key element, as it was in every previous form of information use, is the communication. Communication means here more than technological aspect, because it means personal communication. People, communicating through data exchange, are in front of cost and process time effectiveness. Professionals, but also different others related to construction industry and building product sector, are with new potential of digital construction. A challenging task to implement digital construction is to improve export-import of data, data exchange, cooperation, team-work. Digital construction discloses as task to make the building or infrastructure object comfortable for owner or user.

\section{ACKNOWLEDGEMENTS}

It is to acknowledge for the financial support to the Poznan University of Technology Grant $11-804 / 2017$ (DSPB).

\section{REFERENCES}

1. A. Tomana, BIM. Innowacyjna technologia w budownictwie. Podstawy. Standardy. Narzędzia. PWB Media, Warszawa, 2015.

2. ISO 16739: 2013, IFC specification for data sharing in the construction and facility management industries

3. M. Hooper, BIM Anatomy II - Standardization needs \& support systems, PhD thesis Faculty of Engineering, Lund University, 2015.

4. BuildingSMART International, Report, December 31, 2012

5. A. Glema, BIM education in Poland EDUBIM2016, June 16-17, 2016, ESTP E'cole des Gants Projets, Paris, France, 2016.

6. Digital Built Britain, Level 3 Building Information Modeling - Strategic Plan, HM Government, United Kingdom, February 2015.

7. SIDIR, Stowarzyszenie Inżynierów, Doradców i Rzeczoznawców, BIM protokół, Warszawa, 2016.

8. Sz. Dorna, A. Glema, Procurement and investment procedures and processes in the initial phase of implementation of BIM in Poland, 1BAFC2016, September 13-15, 2016, Glasgow Caledonian University, Glasgow, UK, 2016.

9. Ustawa z dnia 22 czerwca 2016 r. o zmianie ustawy - Prawo zamówień publicznych oraz niektórych innych ustaw, DZIENNIK USTAW RZECZYPOSPOLITEJ POLSKIEJ, poz. 1020, Warszawa, dnia 13 lipca $2016 \mathrm{r}$.

10. DIRECTIVE 2014/24/EU of the EUROPEAN PARLIAMENT and of theCOUNCIL of 26 February 2014 on public procurement and repealing Directive 2004/18/EC, Official Journal of the European Union, L 94/243, March 28, 2014. 


\section{LIST OF FIGURES AND TABLES:}

Fig. 1. Information and its digital transformation in last years: an example of telegram and SMS, constructional documentation, statistics of digital activity in Poland in 2015.

Rys. 1. Informacja i jej transformacja cyfrowa ostatnich lat: : przykład telegramu i SMS, dokumentacja budowlana, statystyka cyfrowej aktywności w Polsce w 2015 roku.

Fig. 2. Components of digital construction: example of BIM model of hospital composed of architecture, construction and MEP modeling; digitalization for the street; example of IFC file -standard of building data import and export; wood as background of application of virtual reality and augmented reality; example of laser scanning of part of altar in Poznan Fara Church.

Rys. 2. Elementy składowe budownictwa cyfrowego: przykład modelu BIM architektury, konstrukcji i instalacji dla projektu szpitala, cyfryzacja ulicy, przykład zbioru w standardzie wymiany danych IFC; środowisko leśne jako przykład wykorzystania wirtualnej rzeczywistości i rozszerzonej rzeczywistości; przykład laserowego skanowania części ołtarza z kościoła farnego w Poznaniu.

Fig. 3. Example of digital construction for infrastructure - CROSSRAIL project - metro station in London. Rys. 3. Przykład cyfrowego budownictwa infrastrukturalnego - projekt CROSSRAIL - stacja metra w Londynie. 


\section{MODELOWANIE DANYCH BUDOWLANYCH BIM - POZIOM BUDOWNICTWA CYFROWEGO}

Slowa kluczowe: inżynieria budowlana, technologia informatyczna, CAD, BIM, gospodarka cyfrowa, budownictwo cyfrowe

\section{STRESZCZENIE:}

Wystarczy spojrzeć na różne branże, poczynając od tak bardzo konserwacyjnej jak muzyka po finanse, poprzez turystykę, fotografię po wydawnictwa, aby zrozumieć tę prawdę i zobaczyć, jakie mają możliwości główne gałęzie przemysłu i jakie zmiany przechodzą. Dzięki postępowi w technologii cyfrowej, wiele innych sektorów zostało przekształconych w ostatniej dekadzie. Do tej pory budownictwo zostało odporne na dokonania cyfrowe widziane w innych sektorach. Jednak takie połączone składniki jak BIM - modelowanie danych budowlanych [1], globalne standardy przetwarzania danych [2], druk 3D, jak również produkcja i montaż poza budową, oddziaływują na wielką bezwładność tego działu gospodarki. Zdolności przystosowania będą miały kluczowe znaczenie dla zapewnienia poprawy uprzemysłowienia, stanowiącego warunek przetrwania, w zarządzaniu opartym na wiedzy i informacji, co w połączeniu z umiejętnym dostarczaniem usług, będzie kluczem do przyszłej przewagi konkurencyjnej. Przystosuj się, nie przegap, budownictwo cyfrowe nadchodzi.

Zadziwiająca jest również statystyka dotycząca elementów cyfrowych na świecie, na poszczególnych kontynentach i w krajach. Dane z 2014 roku i 2015 roku wykazują, że w Polsce zaistniały zmiany. Aktywność użytkowania internetu sięga w Polsce prawie 26 milionów, z wszystkich prawie 39 milionów obywateli. Połowa z użytkowników internetu, 14 milionów Polaków to aktywni członkowie sieci społecznościowych, a liczba urządzeń mobilnych, liczba połączeń mobilnych i liczba 10 milionów użytkowników mobilnych, stawia Polskę wśród pierwszej piątki krajów Europy, to potencjał cyfrowy i podstawowy wymóg komunikacji znajdujący się zapewne w rękach młodych Polaków (Rys. 1).

W połowie 2016 roku zrobiony został w Polsce podstawowy krok ku wdrożeniu technologii BIM [4, 7, 8], znanej i stosowanej zwłaszcza w USA, Skandynawii, a w ostatnich latach najintensywniej w Wielkiej Brytanii [6]. W końcu czerwca została uchwalona, w połowie lipca opublikowana, a w końcu lipca weszła w życie prawne Ustawa Prawo Zamówień Publicznych [9]. Jak jest to zadeklarowane na pierwszej stronie tej ustawy, wdraża ona dyrektywę Unii Europejskiej i Rady Europy [10], co praktycznie oznacza możliwość zastosowania technologii BIM w zamówieniach publicznych w Polsce. Nogami, na których oparty jest BIM to trójwymiarowy 3D model geometrii i dane, dane, dane. Geometria budowli to również dane, zapisane w standardzie IFC [2, 3, 5].

Wirtualna rzeczywistość VR (virtual reality) i rozszerzona rzeczywistość AR (augmented reality) to dwie cyfrowe technologie powiązane z rzeczywistością, które stanowią ścieżki prowadzące do całkowicie innych miejsc. Rzeczywistość wirtualna korzysta z technologii cyfrowej, aby świat cyfrowy odbierać jak prawdziwy, a rozszerzona rzeczywistość wykorzystuje technologię cyfrową, aby prawdziwy świat obierać cyfrowo (Rys. 2). Obie technologie potrzebują coraz większej mocy obliczeniowej i wkrótce zawalczą o naszą uwagę w codziennym życiu zawodowym, w budownictwie i nieruchomościach. 
A czy ta technologia posłużyć może w budowlach historycznych, dziełach dziedzictwa kulturowego ? (Rys. 2) AVR rozszerzona rzeczywistość wirtualna łączy powyższe technologie, pozwalając cyfrowy świat odbierać nie tylko wizualnie, ale cyfrowo. Praca $\mathrm{z}$ danymi równocześnie wyświetlanymi w trakcie odbierania przestrzennego obrazu stanowi o owym rozszerzeniu. Niekiedy, aby nie zakłócać odbioru danych, część wizualną odczytu informacji należy ograniczyć. Właściwe skomponowanie środowiska cyfrowego i dostosowanie obrazu cyfrowego i danych rozszerzających odczyt świata cyfrowego i zróżnicowanie do bieżącej potrzeby wykorzystywania takiego narzędzia dla etapu koncepcji inwestycji, projektowania, wybudowania obiektów i zarządzania nieruchomością jest celem dla powszechnego stosowania technologii budownictwa cyfrowego.

Kolejnym elementem świata cyfrowego i istotnym krokiem rozwoju technologii informacyjnych jest struktura cloud computing. Stanowi ona duży potencjał dla rozwoju modelowania danych budowlanych BIM. Sieci komputerowe, serwery, aplikacje i usługi to różne zasoby informatyczne z dostępem sieciowym. Wszystkie charakteryzują się wygodnym i dostępnym na każde żądanie połączeniem do sieci komputerowej. Klient technologii BIM korzystający z cloud computing ma umożliwione używanie sprzętu komputerowego, uruchamianie programów komputerowych, wykorzystywanie aplikacji komputerowych na różnorodnych urządzeniach jak komputery, tablety, smartfony, a także magazynowanie danych, a zwłaszcza modeli BIM. Korzystanie ze struktury cloud computing w zależności od bardziej lub mniej dostępnych zasobów i różnych potrzeb technologii BIM może przebiegać w wersji prywatnej, zespołowej, publicznej lub mieszanej jako złożonej $\mathrm{z}$ dwóch lub trzech wersji podstawowych. Cloud computing zastosowane z technologią BIM istotnie wzmacnia między innymi współpracę pomiędzy specjalistami tworzącymi modele BIM, proces sprawdzania i eliminowania konfliktów, pracę zespołową, możliwości do nieograniczonego wykorzystywania dokumentacji projektowej na placu budowy oraz działania z zakresu realizacji inwestycji i zarządzania projektami.

Budownictwo charakteryzuje się niską powtarzalnością przedmiotu inwestowania, każdy budynek i obiekt infrastruktury jest inny. BIM i budownictwo cyfrowe stwarza możliwość podwójnego wybudowania. Najpierw tworząc model i wszystkie charakterystyki procesów realizowana jest wirtualna budowa. Po wykorzystaniu narzędzi sprawdzających kolizje i konflikty, po nabyciu doświadczenia w konkretnym projekcie, kolejne, drugie, rzeczywiste budowanie jest efektywniejsze, z mniejszym zużyciem materiałów konstrukcyjnych, lepiej skoordynowane pod względem czasu realizacji i tym samym obarczone mniejszym ryzykiem inwestycyjnym. Wyzwania dla budownictwa do 2025 roku to: prefabrykacja, jakość i dokładność, brak strat-odpadów-śmieci, wszędzie i dużo oprogramowania, internet rzeczy i danych, dużo pomiarów i monitorowanie, duże modele, bazy danych i procesów.

Technologie cyfrowe w ostatniej dekadzie lat sięgają daleko dalej niż znane w budownictwie komputerowe wspomaganie projektowania. Nie tylko liczy się na obliczenia i pomoc w szybkości przygotowania i wykorzystania dokumentacji projektowej. Kluczowym elementem, jak w każdej poprzedniej formie wykorzystania informacji, jest komunikacja osób mających za zadanie efektywnie czasowo i finansowo wykorzystywać dane i udoskonalać pracę zespołową. Stosowanie budownictwa cyfrowego zależy głównie od korzyści dla właściciela i użytkownika budynku lub obiektu infrastruktury. 